\title{
Engineering geologic properties of the Oligocene Kiscell Clay
}

\author{
Péter Görög \\ Department of Construction Materials and \\ Engineering Geology, Budapest University \\ of Technology and Economics, Budapest
}

\begin{abstract}
The Kiscell Clay is the most frequently-occurring rock type of Budapest, especially on the Buda side of the Danube. It occurs near the surface as well as at great depth; for the purposes of this study the upper, approximately 35 meters of the unit was investigated. The results of previous laboratory analyses were collected and more than 2000 test results evaluated. Physical properties such as plasticity index, density, void ratio, and coefficient of compressibility were tested and the results statistically analyzed. Correlation between different properties is shown in graphic form, and equations are proposed to describe the various coefficients.
\end{abstract}

Key words: plasticity index, density, void ratio, coefficient of compressibility, correlation, plasticity diagram

\section{Occurrence of the Kiscell Clay}

The Kiscell Clay (hereafter abbreviated to $\mathrm{KC}$ ) is a rock showing great variability; it behaves mainly as a plastic soil, and sometimes as a weak rock (Fig. 1).

The uppermost part of the $\mathrm{KC}$ is a weathered zone of yellow color, which is brecciated in some places. In the strata of this cover zone, carbonate was leached and pyrite and other iron minerals turned to limonite. This is related to a hypergenetic process, which occurred in the Early Pleistocene (Kalmár et al. 2003). In 1932 Vendl described the genesis of the upper, yellow, weathered part: during the weathering process the pyrite content of the solid $\mathrm{KC}$ oxidizes and turns to limonite, which changes the color of the KC. The clay has a good load-

Address: P. Görög: H-1111 Budapest, Stoczek u. 2, Hungary, e-mail: gorog.peter@gmail.com Received: November 5, 2007; accepted: January 2, 2008 


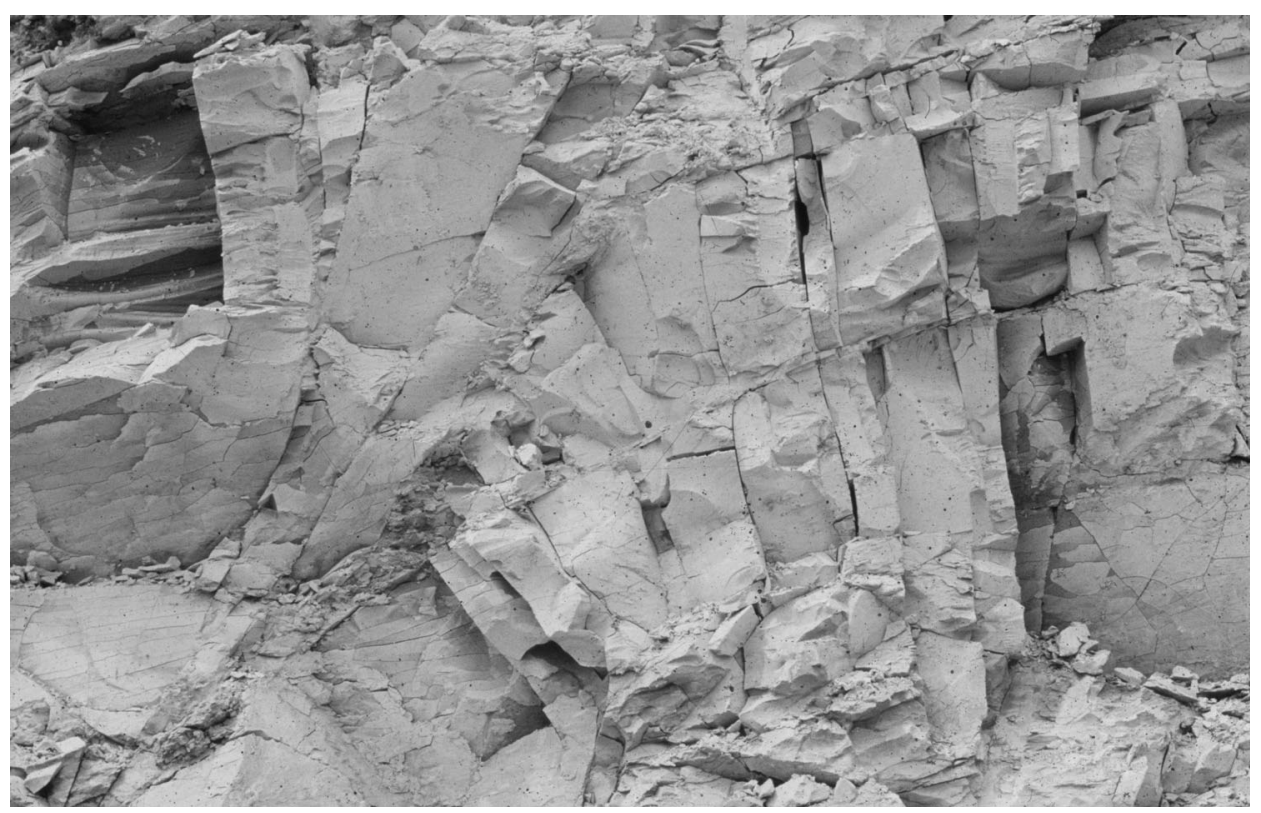

Fig. 1

Kiscell Clay in Pilisborosjenő, in its rock-like state (photo: Dr. Béla Kleb)

bearing capacity in its original depositional form, but its weathered part is sensitive to the effect of the water, usually causing slipping (Fodor and Kleb 1986).

In cores cut in the Buda section of the underground Metro line 4, the KC was subdivided into three zones on the basis of RQD values. The first is the upper, weathered, broken and expanded zone; this includes the upper, yellow weathered part of the $\mathrm{KC}$, as well as its upper broken and expanded part of unweathered, gray clay. The second is the expanded and cracked zone, which lies 10-20 meters below the surface. The third zone is beneath the clay expansion boundary; this is where the sediment behaves like a weak rock (Horváth et al. 2000). This subdivision was already previously identified by Hegyi et al. (1981); they established the three-fold system on the basis of the number of slip surfaces on core samples. According to this system the frequency of slip surfaces decreases with increasing depth. This is due to vertical expansion, since the change of geologic stress was greater than the elastic deformation of the rock.

Usually the $\mathrm{KC}$ is a non-compact sediment, where soil mechanical methods should be applied to determine its physical properties. Sometimes this type of clay is a compact sedimentary rock like the Buda Marl. Its bedding thickness is very high; therefore its deepest part (30 meters or deeper) is much harder. In this case the determination of the physical properties of this clay is not easy; it is too hard for undisturbed geotechnical sampling, but not hard enough to drill a cylindrical core sample for laboratory strength tests. This is the type of KC encountered along Metro line 4 (Fig. 2). 


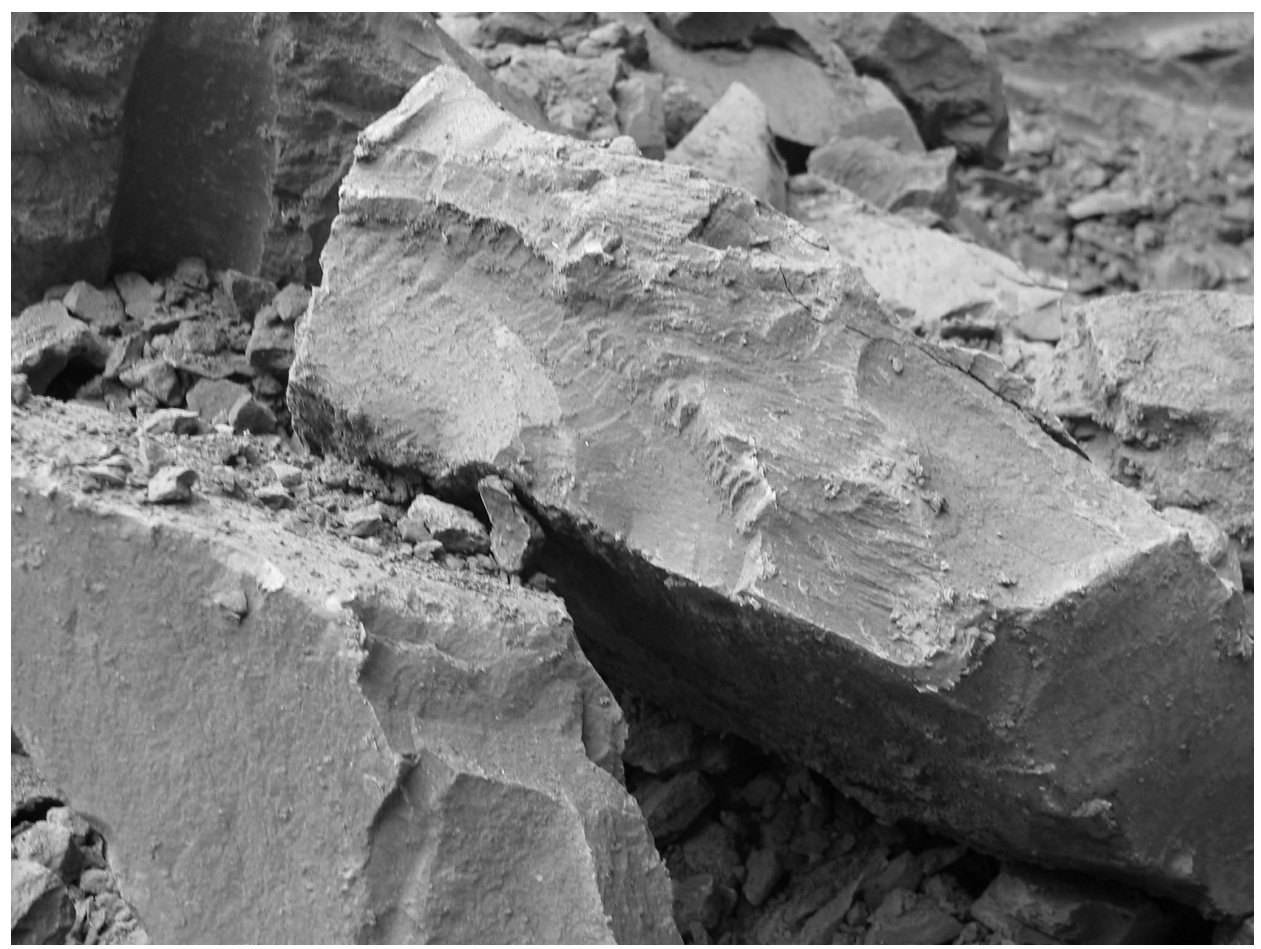

Fig. 2

Kiscell Clay from the construction pit of Metro Line 4 at Etele Square

For the purposes of this study several soil physical parameters of the $\mathrm{KC}$ were collected. Many geotechnical reports were examined and any useful data thereof collected. Such data is particularly useful if in addition to identification analyses there are some strength analyses as well.

The bulk of the collected data was prepared by the laboratory of Fômterv Co., Geohidro Geotechnikai Ltd., and Mélyépterv Co., and was obtained from the database of the Hungarian Geological Institute.

\section{The investigated soil physical properties}

In the first part of this paper the three basic zones of the $\mathrm{KC}$ were described: the upper yellow, weathered and broken zone, the gray, fresh but cracked zone down to a depth of 30 meters, and below that, at greater depth, gray, fresh sediment in its original state. This paper concerns itself with the upper two zones of the $\mathrm{KC}$, which can also be differenced by pyrite and limonite content. In the upper, weathered zone pyrite was transformed to limonite; this limonite content gives the clay its yellow color (Vendl 1932). The second zone was not affected by 
weathering; it is thus in fresh condition and is of gray color. Figure 3 shows the transition zone between the yellow and gray clay in a core cut at Etele Square.

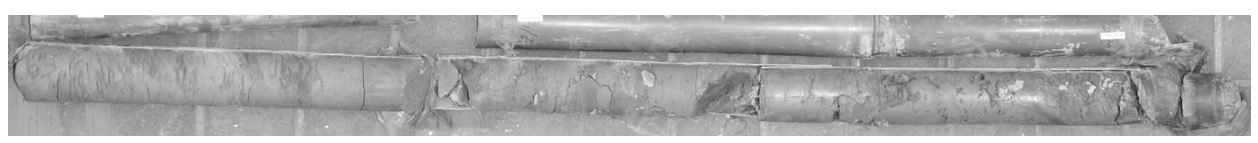

Fig. 3

Transition between the weathered yellow and fresh gray zone of the Kiscell Clay in a core cut at Etele Square

The data of the two zones were investigated separately. The stronger part of the KC would better be referred to as a clay-marl. The elastic modulus of the marly $\mathrm{KC}$ is usually determined, but for the clayey type of the $\mathrm{KC}$ only the coefficient of compressibility is generally established. Over 1000 data of both zones of the KC were collected. The main statistical parameters of the yellow KC are presented in Table 1, and those of the gray KC in Table 2.

Table 1

Main statistical characteristics of soil physical parameters: upper yellow, weathered part of the Kiscell Clay

\begin{tabular}{|l|c|c|c|c|c|c|c|}
\hline \multicolumn{2}{|c|}{ Type of data } & $\begin{array}{c}\text { No. of } \\
\text { samples }\end{array}$ & Mean & $\begin{array}{c}\text { Standard } \\
\text { deviation }\end{array}$ & Min. & Median & Max. \\
\hline Water content & $\mathrm{w}[\%]$ & 169 & 18.3 & 4.8 & 7.9 & 18.0 & 31.7 \\
\hline Plasticity limit & $\mathrm{w}_{\mathrm{P}}[\%]$ & 116 & 21.4 & 4.2 & 14.0 & 21.0 & 34.0 \\
\hline Liquid limit & $\mathrm{w}_{\mathrm{L}}[\%]$ & 137 & 46.4 & 10.6 & 26.0 & 46.5 & 78.0 \\
\hline Plasticity index & $\mathrm{I}_{\mathrm{P}}[\%]$ & 136 & 25.6 & 7.6 & 11.0 & 26.2 & 51.0 \\
\hline Consistency index & $\mathrm{I}_{\mathrm{C}}[\%]$ & 144 & 1.08 & 0.19 & 0.37 & 1.10 & 1.60 \\
\hline Density & $\rho_{\mathrm{w}}\left[\mathrm{kg} / \mathrm{m}^{3}\right]$ & 81 & 1940 & 130 & 1530 & 1950 & 2200 \\
\hline Void ratio & $\mathrm{e}[-]$ & 78 & 0.69 & 0.12 & 0.43 & 0.69 & 0.99 \\
\hline Degree of saturation & $\mathrm{Sr}[-]$ & 50 & 0.75 & 0.16 & 0.37 & 0.77 & 1.00 \\
\hline Coeff. of compressibility & $\mathrm{E}_{\mathrm{S}}\left[\mathrm{MN} / \mathrm{m}^{2}\right]$ & 49 & 12.0 & 2.6 & 6.7 & 11.3 & 20.0 \\
\hline Angle of friction & $\Phi\left[{ }^{\circ}\right]$ & 38 & 22.2 & 4.1 & 16.0 & 22.0 & 34.3 \\
\hline Cohesion & $\mathrm{c}[\mathrm{kPa}]$ & 41 & 54.5 & 24.6 & 20.4 & 50.0 & 117.0 \\
\hline Carbonate content & $\mathrm{CaCO}_{3}[\%]$ & 24 & 16.4 & 9.7 & 0.8 & 14.0 & 37.6 \\
\hline
\end{tabular}

The collected data were statistically evaluated and correlations established between individual soil-physical parameters. The collected parameters were determined in least four different laboratories; therefore the individual tests contain different errors. Especially the triaxial test is very sensitive to the testing process; breaking speed, for example, greatly influences shear strength parameters. The influence of breaking speed is greater when testing soft clay 
Table 2

Main statistical characteristics of soil physical parameters: deeper gray, fresh part of the Kiscell Clay

\begin{tabular}{|l|c|c|c|c|c|c|c|}
\hline \multicolumn{2}{|c|}{ Type of data } & $\begin{array}{c}\text { No. of } \\
\text { samples }\end{array}$ & Mean & $\begin{array}{c}\text { Standard } \\
\text { deviation }\end{array}$ & Min. & Median & Max. \\
\hline Water content & $\mathrm{w}[\%]$ & 144 & 16.6 & 4.3 & 1.4 & 16.0 & 27.6 \\
\hline Plasticity limit & $\mathrm{w}_{\mathrm{P}}[\%]$ & 131 & 23.0 & 3.4 & 15.0 & 22.5 & 32.0 \\
\hline Liquid limit & $\mathrm{w}_{\mathrm{L}}[\%]$ & 134 & 52.6 & 6.9 & 33.0 & 53.1 & 69.7 \\
\hline Plasticity index & $\mathrm{I}_{\mathrm{P}}[\%]$ & 134 & 29.5 & 5.7 & 16.0 & 30.0 & 47.0 \\
\hline Consistency index & $\mathrm{I}_{\mathrm{C}}[\%]$ & 133 & 1.22 & 0.17 & 0.80 & 1.24 & 1.65 \\
\hline \multirow{2}{*}{ Density } & $\rho_{\mathrm{w}}\left[\mathrm{t} / \mathrm{m}^{3}\right]$ & 123 & 2180 & 120 & 1850 & 2190 & 2470 \\
\cline { 2 - 9 } & $\rho_{\mathrm{d}}\left[\mathrm{t} / \mathrm{m}^{3}\right]$ & 72 & 1950 & 100 & 1680 & 1990 & 2100 \\
\hline Void ratio & $\mathrm{e}[-]$ & 97 & 0.46 & 0.11 & 0.30 & 0.44 & 0.80 \\
\hline Degree of saturation & $\mathrm{Sr}_{[-]}$ & 11 & 0.78 & 0.15 & 0.54 & 0.85 & 0.95 \\
\hline Coeff. of compressibility & $\mathrm{E}_{\mathrm{S}}\left[\mathrm{MN} / \mathrm{m}^{2}\right]$ & 20 & 15.8 & 13.8 & 8.1 & 11.9 & 70.0 \\
\hline Angle of friction & $\Phi\left[{ }^{\circ}\right]$ & 49 & 25 & 11 & 5 & 24 & 43 \\
\hline Cohesion & $\mathrm{c}[\mathrm{kPa}]$ & 52 & 211 & 120 & 16 & 200 & 400 \\
\hline Elastic module & $\mathrm{E}[\mathrm{MPa}]$ & 40 & 75 & 47 & 9 & 77 & 200 \\
\hline Poisson's ratio & $v[-]$ & 18 & 0.26 & 0.05 & 0.18 & 0.26 & 0.35 \\
\hline Carbonate content & $\mathrm{CaCO}_{3}[\%]$ & 33 & 15.1 & 4.7 & 8.0 & 14.6 & 34.1 \\
\hline
\end{tabular}

with high water content, than hard clay. The investigated KC samples are usually hard; therefore the differences in breaking speed have less influence on the results. The error due to different testing processes did, however, influence the accuracy of the statements in this paper.

Only occasionally is it possible to properly determine the tightness of the correlation based on the value of correlation coefficients of the different physical properties. A zero or low value of the correlation coefficient is not a sure indicator that there is no correlation between the two variables. The significance analyses show the probability of a zero value of the correlation coefficient. Such analyses should be carried out by t-probe when the statistical variable shows a normal distribution (Rétháti 1985). Paál (1975) presented a graph of the results of the tprobe, so the probability of correlation can easily be determined.

\section{Composition of the Kiscell Clay}

The composition of the KC by grain size distribution is $40-50 \%$ clay fraction, 50-60\% silt, and only 6-7\% sand. Its upper layers contain 20-30\% clay fraction and $70-80 \%$ silt. Therefore the petrologic name of the upper part of the KC is clay/ marly silt, and for its deeper layers silty clay/marl (Báldi 1983). Several grain-size distribution data were collected from the database of the Hungarian Geological Institute, and plotted on a graph (Fig. 4). According to this the silt and clay 
content of the upper layers of the solid KC is the same as in Báldi (1983), but the sand content is higher in almost all the samples.

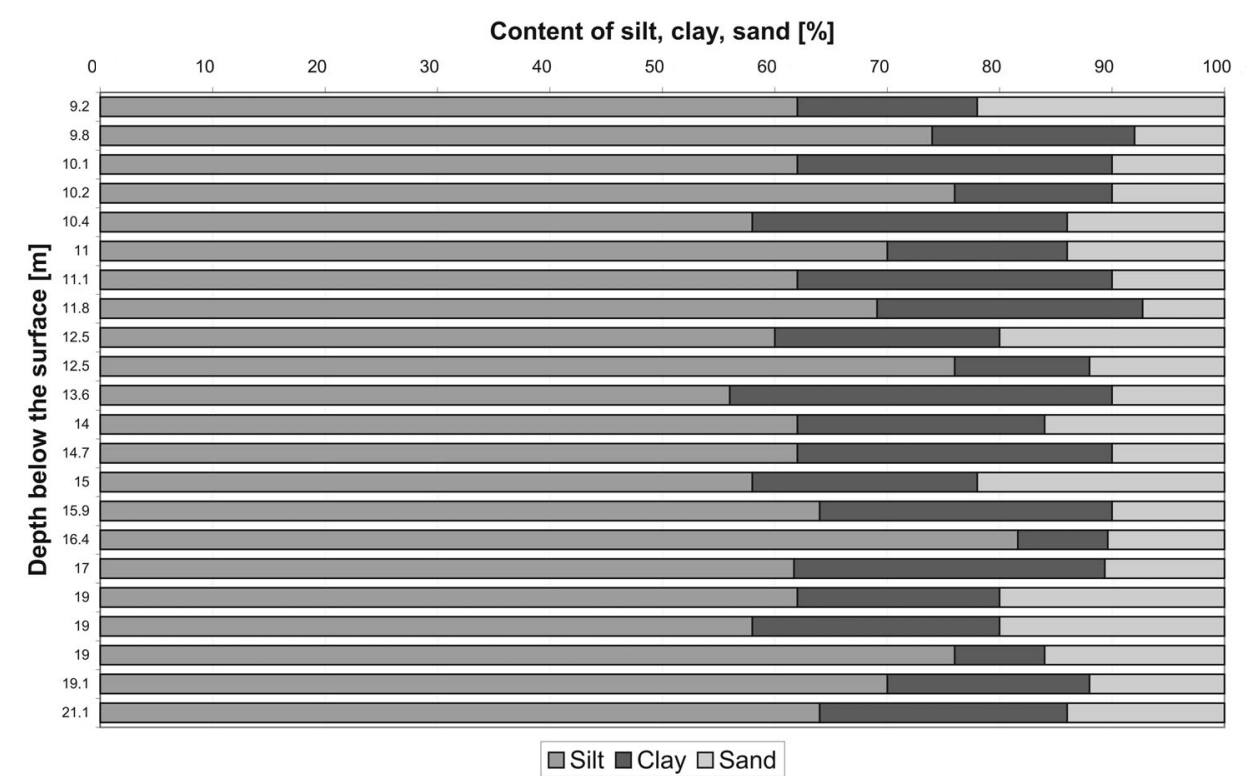

Fig. 4

Clay, siltstone and sand content of the upper part of the gray KC (data from MÁFI 1985)

The carbonate content of the KC at different depths is shown in Fig. 5 (yellow $\mathrm{KC}$ ) and Fig. 6 (gray KC). The carbonate content of the yellow KC changes over a wide range, while that of the gray one shows no characteristic differences. The graphs confirmed the statement by Báldi (1983) that the carbonate content of the $\mathrm{KC}$ ranges between 10 and 35\%, although in some sample of the yellow $\mathrm{KC}$ it is less than $10 \%$.

\section{Correlation analyses}

Wet and dry density and void ratio were plotted against sample depth. The yellow, weathered part of the KC usually occurs down to a depth of 10-15 meters; the structure of the clay does not change statistically within such a shallow depth. This fact basically determines the relationships based on sample depths. The gray KC characteristically occurs below a depth of 10 meters. Data for the gray $\mathrm{KC}$ were encountered down to a depth of 35 meters; therefore the results of this study can be considered valid to this depth.

The two types of KC complement each other from the point of view of natural stratification: the gray part always occurs beneath the yellow weathered one; therefore, in this relationship, any separation of the two types of clay is 


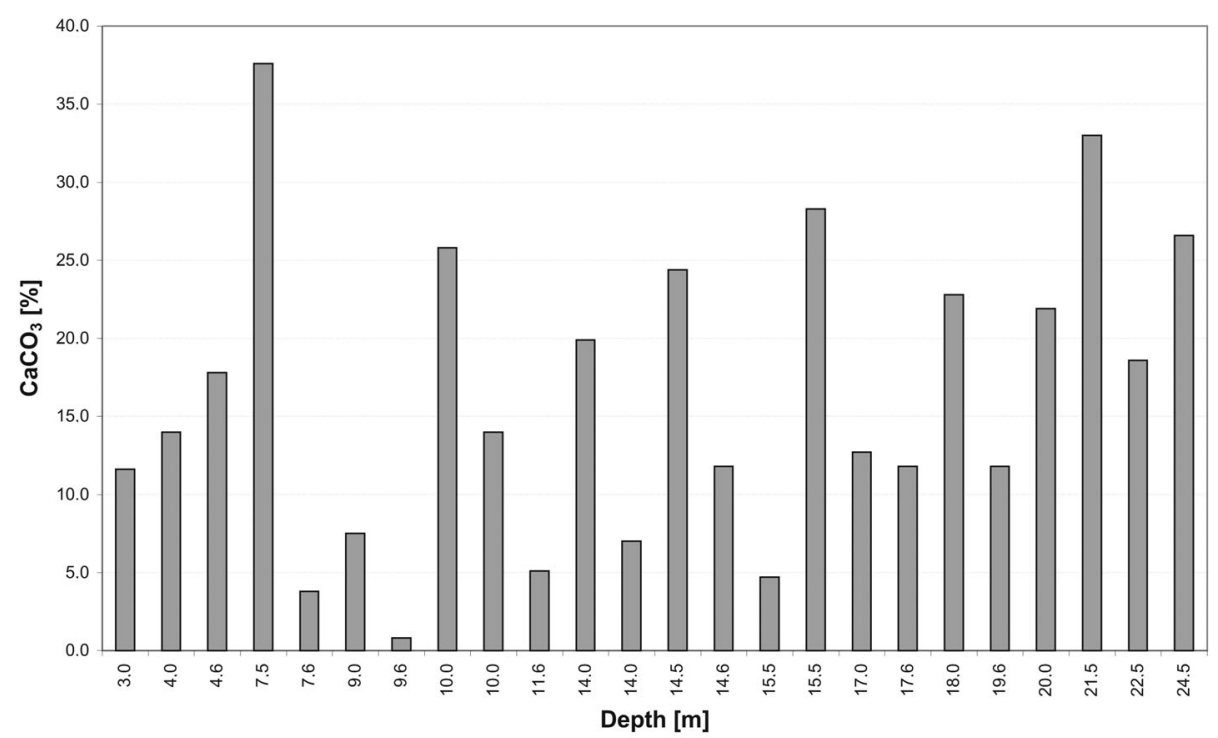

Fig. 5

Carbonate content of the yellow Kiscell Clay

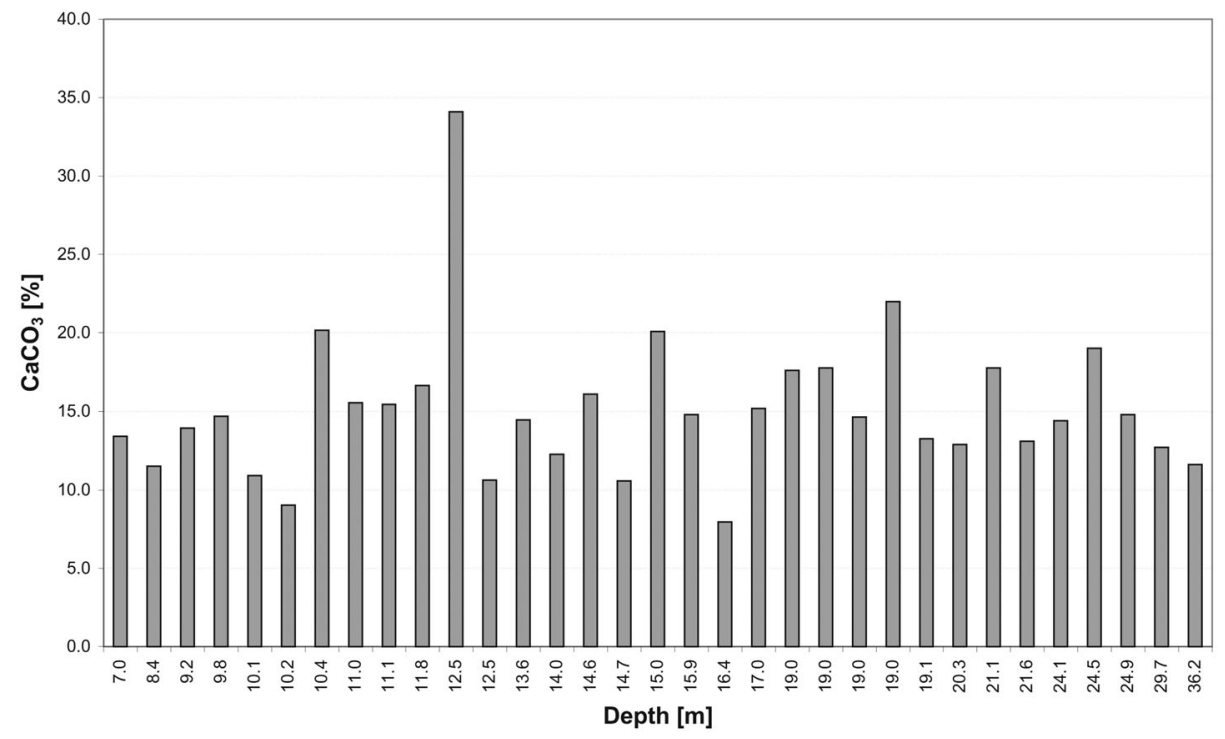

Fig. 6

Carbonate content of the gray Kiscell Clay 
unnecessary. The correlation between wet density and sample depth is presented in Fig. 7: the data points of the two types of clay largely overlap. For the case of exponential regression of the equation of the curve

$$
\rho_{w}\left[\mathrm{~kg} / \mathrm{m}^{3}\right]=\frac{\ln \left(\frac{d[\mathrm{~m}]}{0.025}\right)}{0.003}
$$

the correlation coefficient is $r=0.67$. The change in density ceases at the value of $2300 \mathrm{~kg} / \mathrm{m}^{3}$; at greater depth the curve would converge with the vertical line of $2300-2400 \mathrm{~kg} / \mathrm{m}^{3}$ (Fig. 7).

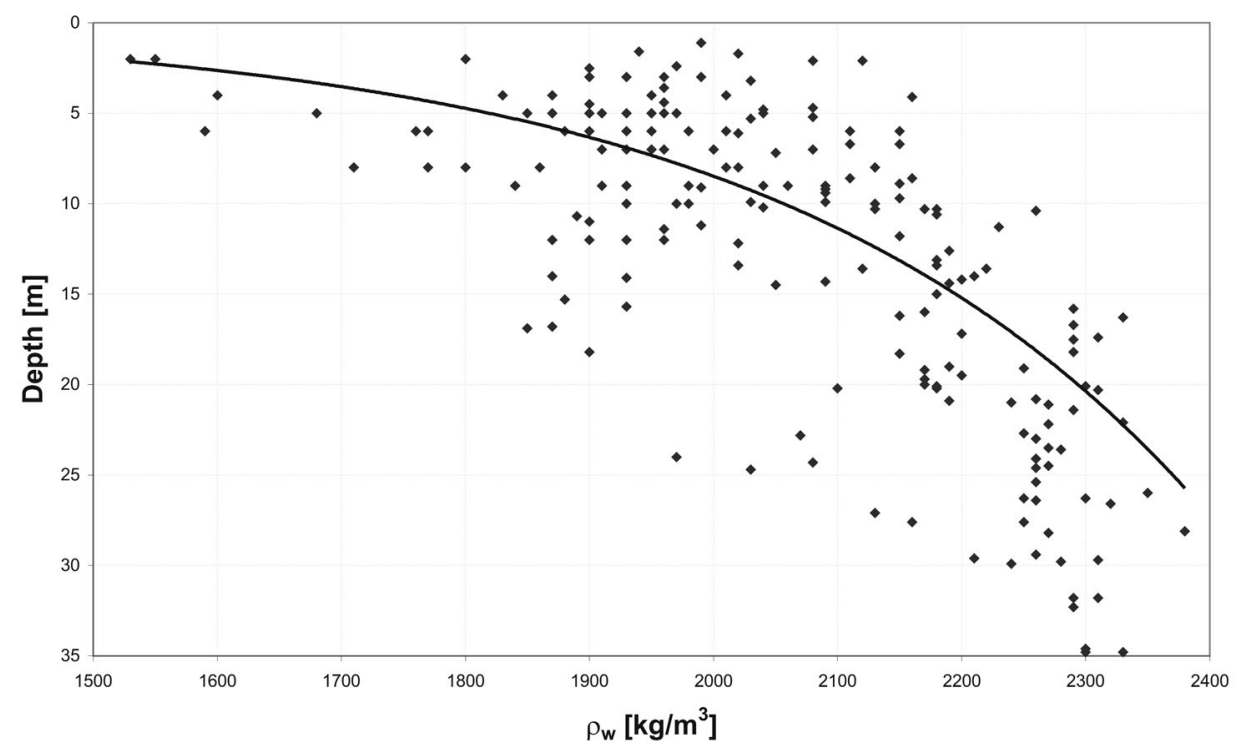

Fig. 7

Relationship between depth and wet density of the KC

There is also no need to distinguish the two zones of the KC by investigating the correlation of depth and void ratio. In this case the best approximation can be reached with the involute function

$$
e=\left(\frac{m[m]}{3.34}\right)^{-0.55}
$$

(Fig. 8), of which the correlation coefficient is $r=0.73$. The value of the void ratio decreases at a lower rate with increasing depth, and below a representative depth it will be constant, taking the involute function into consideration. According to the collected data the value of the void ratio of the $\mathrm{KC}$ is not lower than 0.3 . 


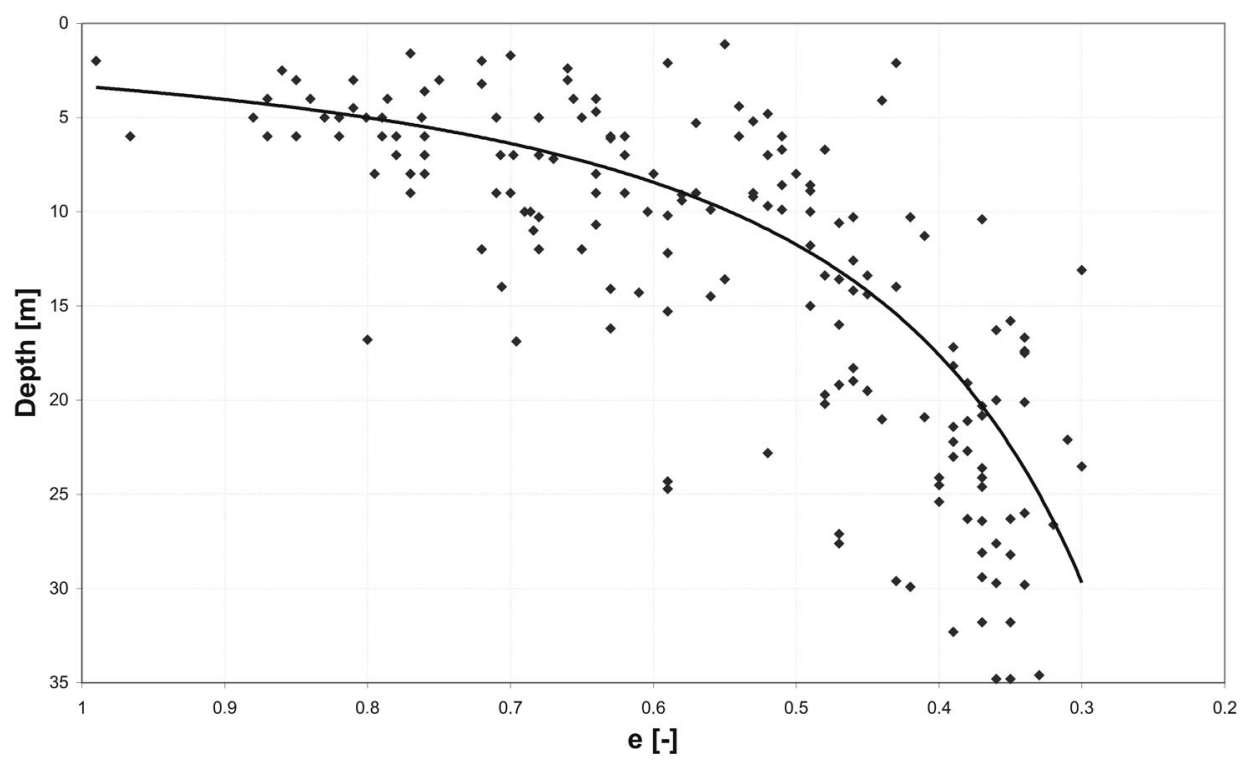

Fig. 8

Relationship between sample depth and void ratio of the KC by involute function

Density was analyzed as a function of void ratio; for the gray $\mathrm{KC}$, the relationship between wet and dry density was also analyzed.

The best approximation was obtained by a linear relationship. For wet density and void ratio of the yellow $\mathrm{KC}$, the equation is $\rho_{w}\left[\mathrm{~kg} / \mathrm{m}^{3}\right]=2513-826$ e (Fig. 9), and the value of the correlation coefficient is $r=0.78$. For the gray $\mathrm{KC}$ the equation dealing with the same properties is $\rho_{w}\left[\mathrm{~kg} / \mathrm{m}^{3}\right]=2630-946 e$ (Fig. 9), with a correlation coefficient of $\mathrm{r}=0.94$. The correlation for the gray $\mathrm{KC}$ is better than for the yellow one because of the difference in void ratio of the different types of clay. The average void ratio of the yellow $\mathrm{KC}$ is 0.69 , and 0.46 for the gray type. The value of wet density is affected by the saturation of the samples; therefore the influence of varying degrees of saturation of the samples is less in the case of the gray KC than the yellow one, again because of the lower void ratio. In Fig. 9 it can be seen that the spread of data points is wider when the void ratio is higher.

Void ratio and dry density of the gray KC were compared (Fig. 10). In this case saturation has no effect on the material, so the points should plot on one line; because of slight differences in material density, however, small divergences from the line can occur. In this case the correlation is very strong; the void ratio is $\mathrm{r}=$ 0.97 and the equation of the line: $\rho_{\mathrm{d}}\left[\mathrm{kg} / \mathrm{m}^{3}\right]=2522-1375 e$.

For the case of the gray KC it was possible to compare wet and dry density (Fig. 11).

In this case the disposition of the points on the plot depends upon saturation and void ratio. At $100 \%$ saturation the relationship would depend only upon void ratio, and saturated density could be calculated with the equation: 


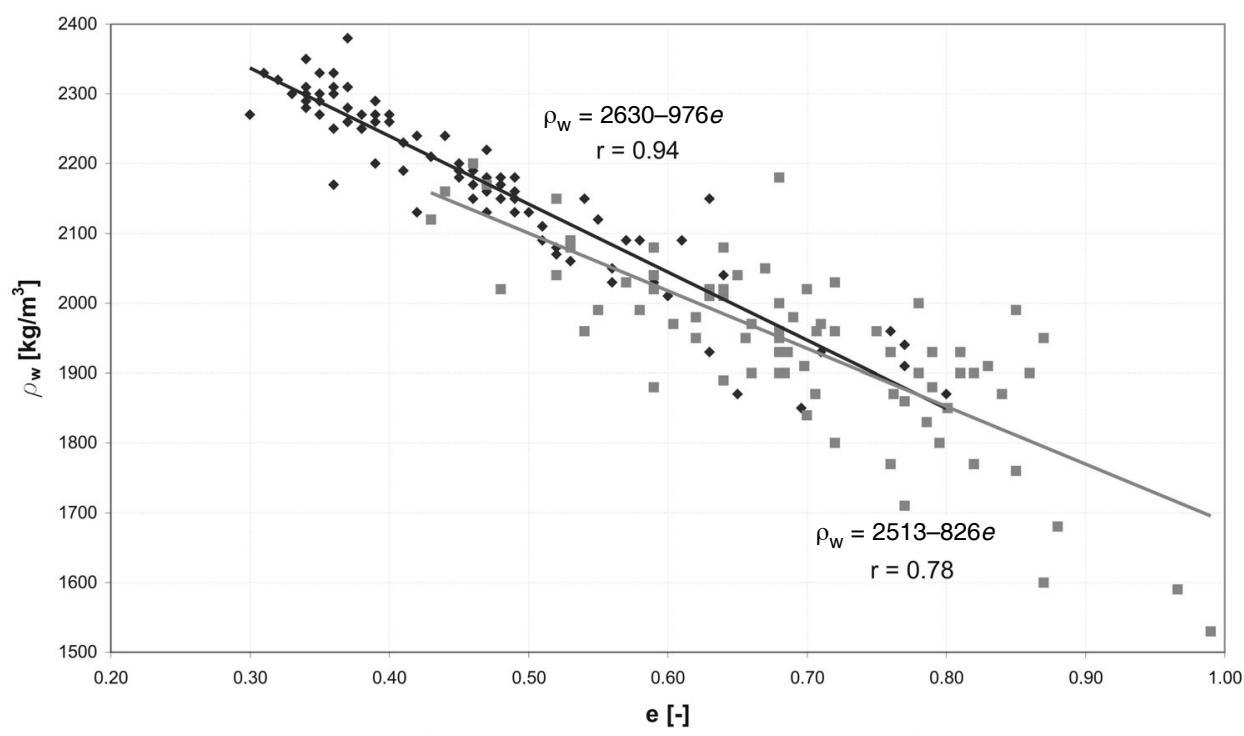

Fig. 9

Correlation between wet density and void ratio of both types of Kiscell Clay

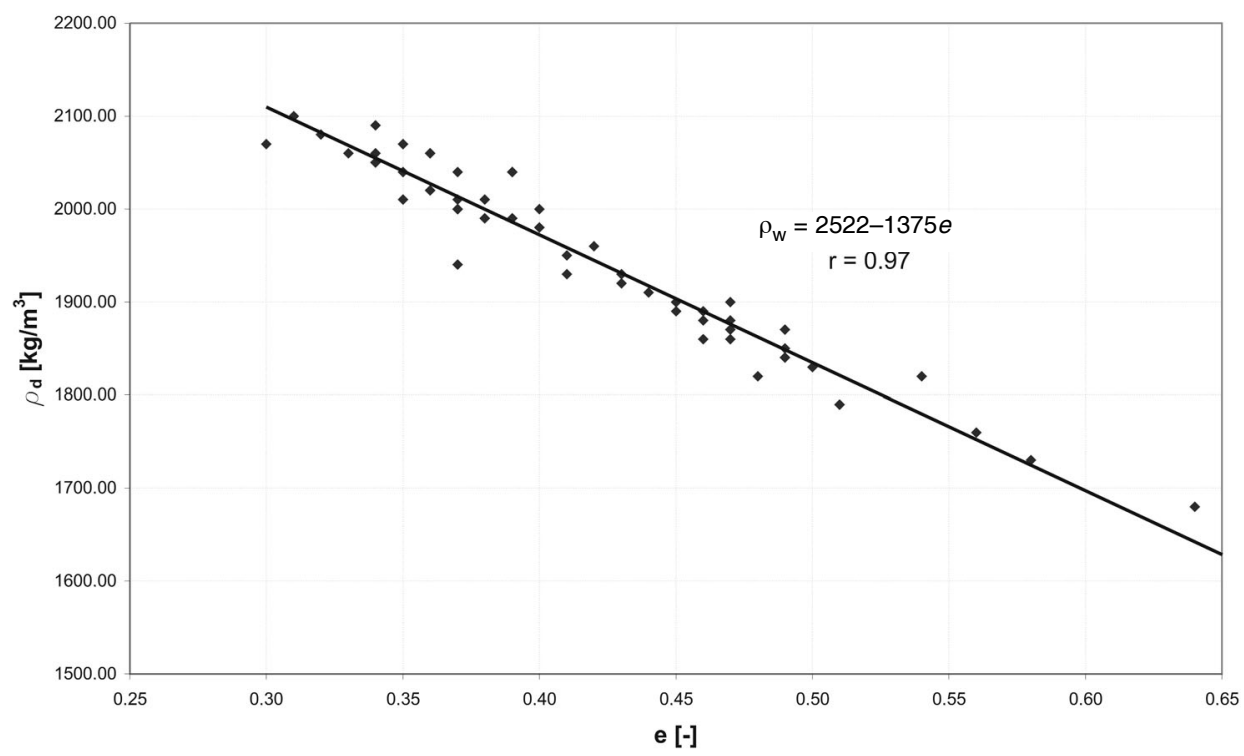

Fig. 10

Relationship between void ratio and dry density of the gray Kiscell Clay

$\rho_{s}=\rho_{d}+[e /(1+e)] \rho_{\text {water }}$. The correlation of wet and dry density was plotted in Fig. 11. The equation of the regression line is $\rho_{w}\left[\mathrm{~kg} / \mathrm{m}^{3}\right]=0.69 \rho_{d}\left[\mathrm{~kg} / \mathrm{m}^{3}\right]+887$. The correlation coefficient is $r=0.92$, which indicates strong correlation; this is due 


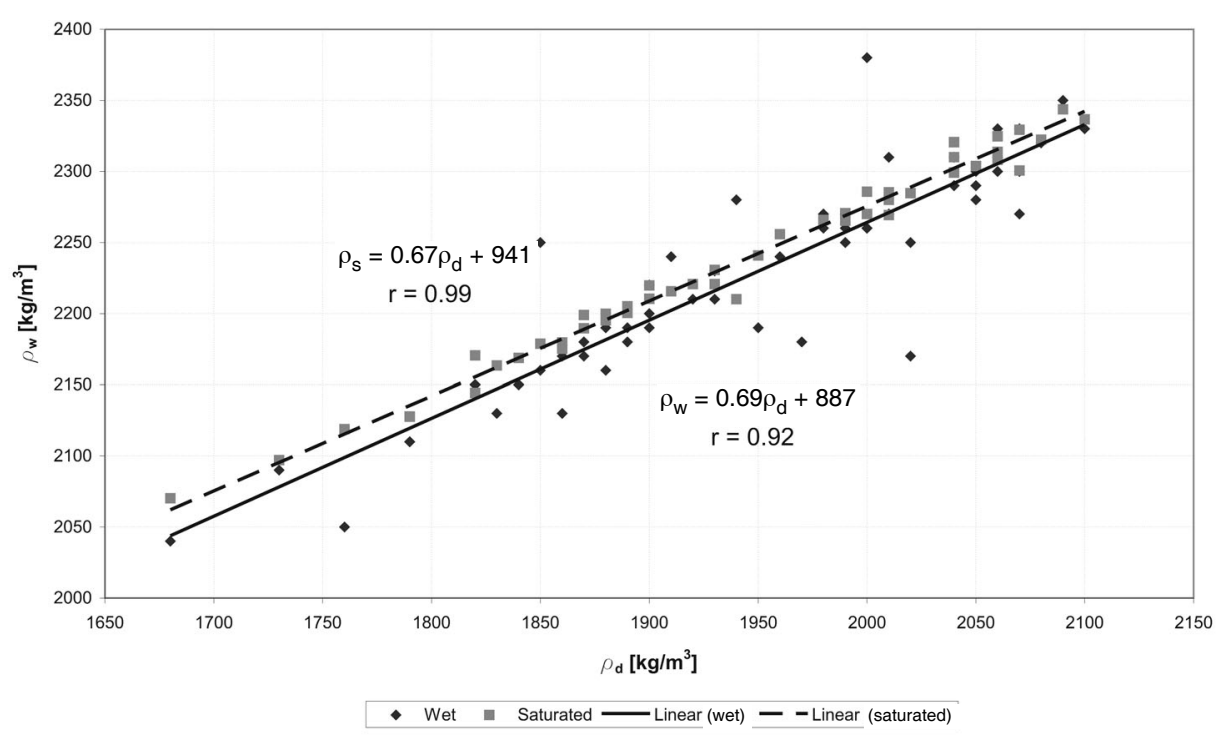

Fig. 11

Relationship between wet and dry density of the gray Kiscell Clay, with the theoretical line of saturated condition

to the high average saturation rate of the gray $\mathrm{KC}(\mathrm{Sr}=0.80)$. The points of saturated condition were plotted in Fig. 11 along with the fitted line; the correlation coefficient is $\mathrm{r}=0.99$. There should be no points above the line of saturated condition; any points above this line are due to measurement error.

The coefficient of compressibility showed the best correlation with the consistency index. The correlation coefficient for the yellow KC is $r=0.79$, and 0.87 for the gray unit. Despite the good correlation, significance analyses were carried out as well because of the small number of data pairs, especially for the gray KC. The probability of the supposed correlation is close to $100 \%$ according to the result of the significance analyses. The equation of the regression line for the yellow $\mathrm{KC}$ is $E_{S}\left[M N / \mathrm{m}^{2}\right]=12.2 I_{c}[-]-1.3$, and $E_{s}\left[M N / \mathrm{m}^{2}\right]=13.4 I_{c}[-]-2.6$ for the gray $\mathrm{KC}$. The regression line of the gray unit is steeper than that of the yellow $\mathrm{KC}$, which proved that the coefficient of compressibility of the clay in fresh condition is higher than for the upper weathered zone.

The relationship between coefficient of compressibility and consistency index, which is easily determined, is such that the coefficient of compressibility of the $\mathrm{KC}$ can be estimated. A consistency index below 1.00 is rare for the gray $\mathrm{KC}$, as proved by the collected data (Fig. 13); therefore the relationship for the gray KC is valid when Ic $\geq 1.00$. 


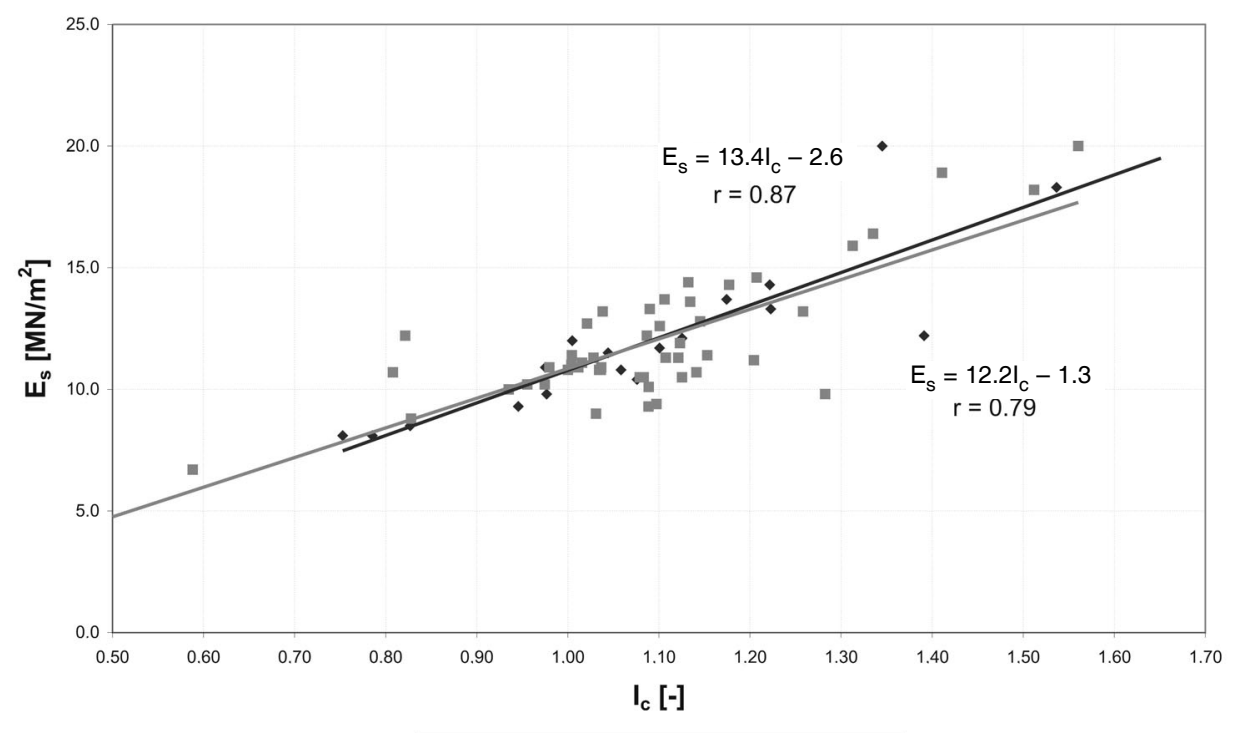

Fig. 12

- Grey $=$ Yellow — Linear (grey) —Linear (yellow)

Relationship between coefficient of compressibility and consistency index of both types of Kiscell Clay

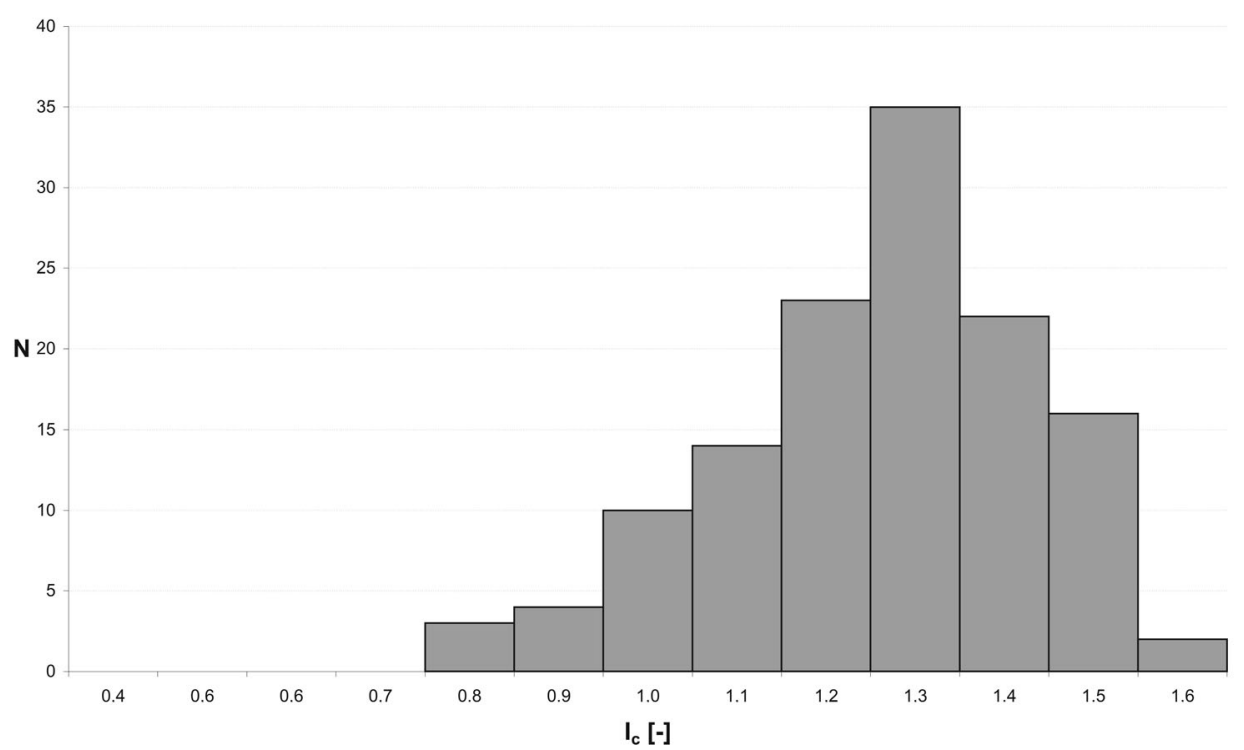

Fig. 13

Frequency distribution of the consistency index for the gray Kiscell Clay

Central European Geology 50, 2007 


\section{Geographic analyses of the investigated data}

The investigated data are from different areas of Budapest. Most of the data are from Óbuda and Lágymányos, but some were collected from Rózsadomb and Budaörs as well (Fig. 14); therefore a location comparison of different data is possible.

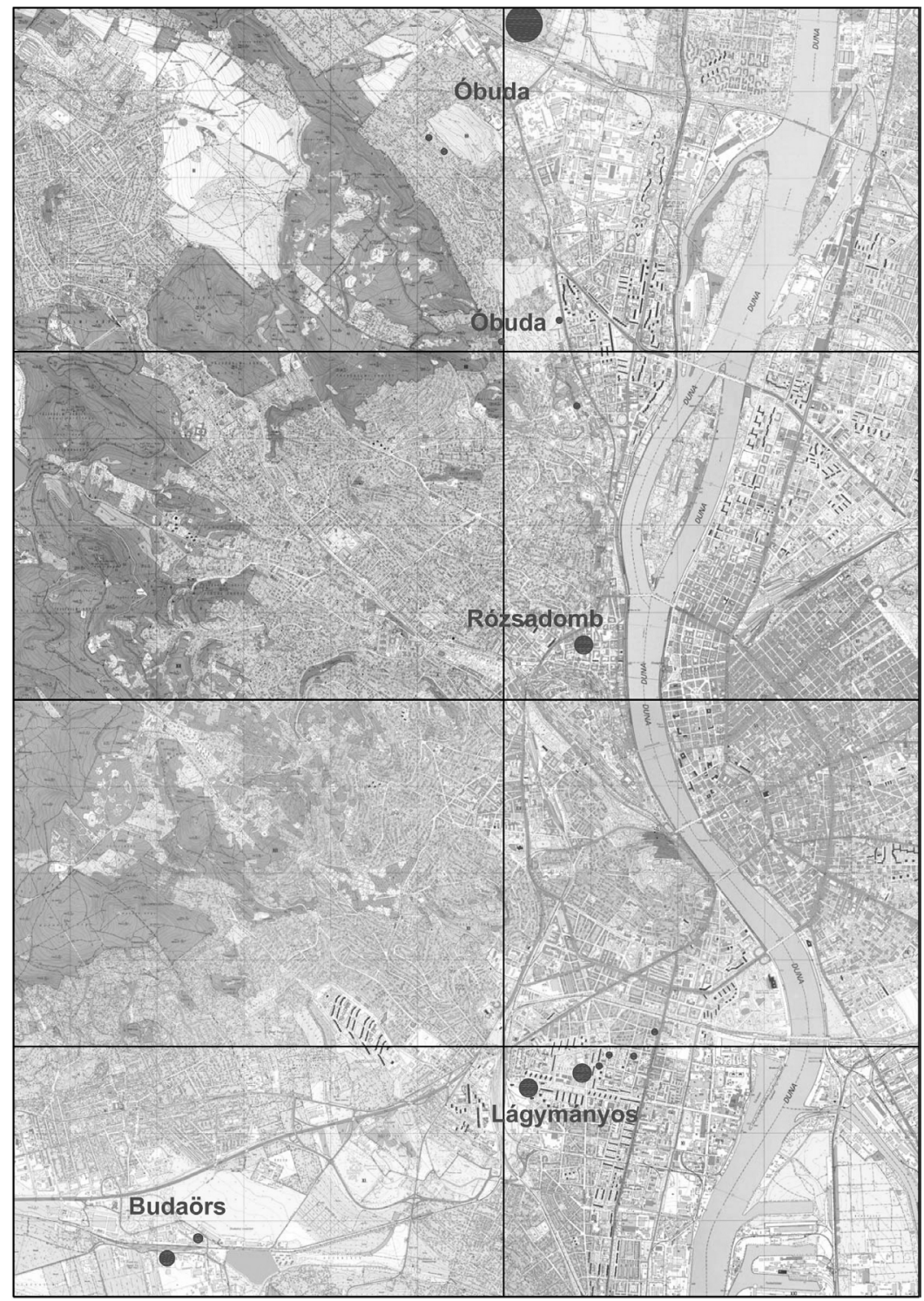

Fig. 14

Location of the investigated data 
To begin with the data from different locations were plotted on a plasticity diagram (Fig. 15).

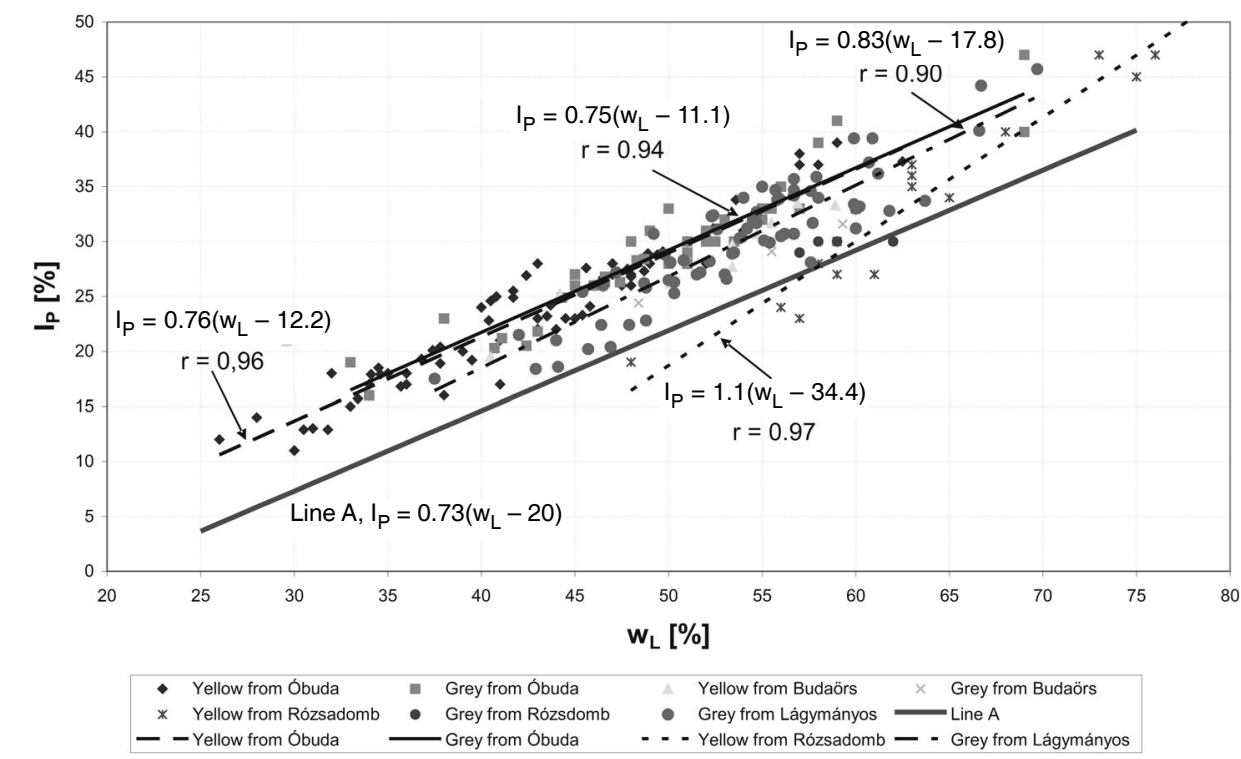

Fig. 15

Plasticity diagram with the data from different locations

There is no significant difference between the yellow and gray type of the Óbuda KC; the two fitted lines are almost identical. The equation for the yellow $\mathrm{KC}$ from Óbuda $I_{p}=0.75\left(w_{L}-12.2\right)$ and that for the gray type $I_{p}=0.75\left(w_{L}-11.1\right)$ provided the best fit to the data point set. The correlation coefficients were $\mathrm{r}=$ 0.96 and $\mathrm{r}=0.94$, respectively.

The line of the gray KC from Lágymányos is closer to the A-line of Casagrande; its equation is $I_{p}=0.83\left(w_{L}-17.8\right)$ and the correlation coefficient $\mathrm{r}=0.90$.

The line of the KC from Rózsadomb crosses the A-line, which could mean that it has some organic content; at this location, however, the KC and Tard Clay are in proximity, as shown by the geologic map; therefore data points of both clay units could be mixed.

The evolution of the $\mathrm{KC}$ on the Buda side is not uniform: differences are evident in various areas. The proximity of the trend lines of the yellow and gray types of KC show a greater similarity for yellow and gray types from the same locality, than for gray types from differing localities (for example the gray $\mathrm{KC}$ from Óbuda and that from Lágymányos).

The equations for the yellow and gray types of the KC from Óbuda are close to those determined by Paál (1975), such as the one for the yellow type $I_{p}=$ $0.77\left(w_{L}-15.6\right)$ and for the gray one $I_{p}=0.77\left(w_{L}-16.8\right)$. 
The areal relationship between void ratio and wet density is plotted in Fig. 16 . The void ratio of the gray KC is smaller than that of the yellow one because the yellow part is weathered and loosened. The most compact clay is from Lágymányos. The void ratio $(0.40-0.99)$ and the density $\left(1500-2200 \mathrm{~kg} / \mathrm{m}^{3}\right)$ of the KC from Óbuda vary over a wide range. The Óbuda clay sample data points of the yellow and gray units do not show a definite separation, but an examination of the average values shows that the gray clay has higher density and lower void ratio. Comparing the clay samples from Óbuda and from Rózsadomb it can be observed that those from Rózsadomb have a higher void ratio with the same density, which indicates some differences in composition. Data points of Budaörs clay could not be distinguished from those of Óbuda.

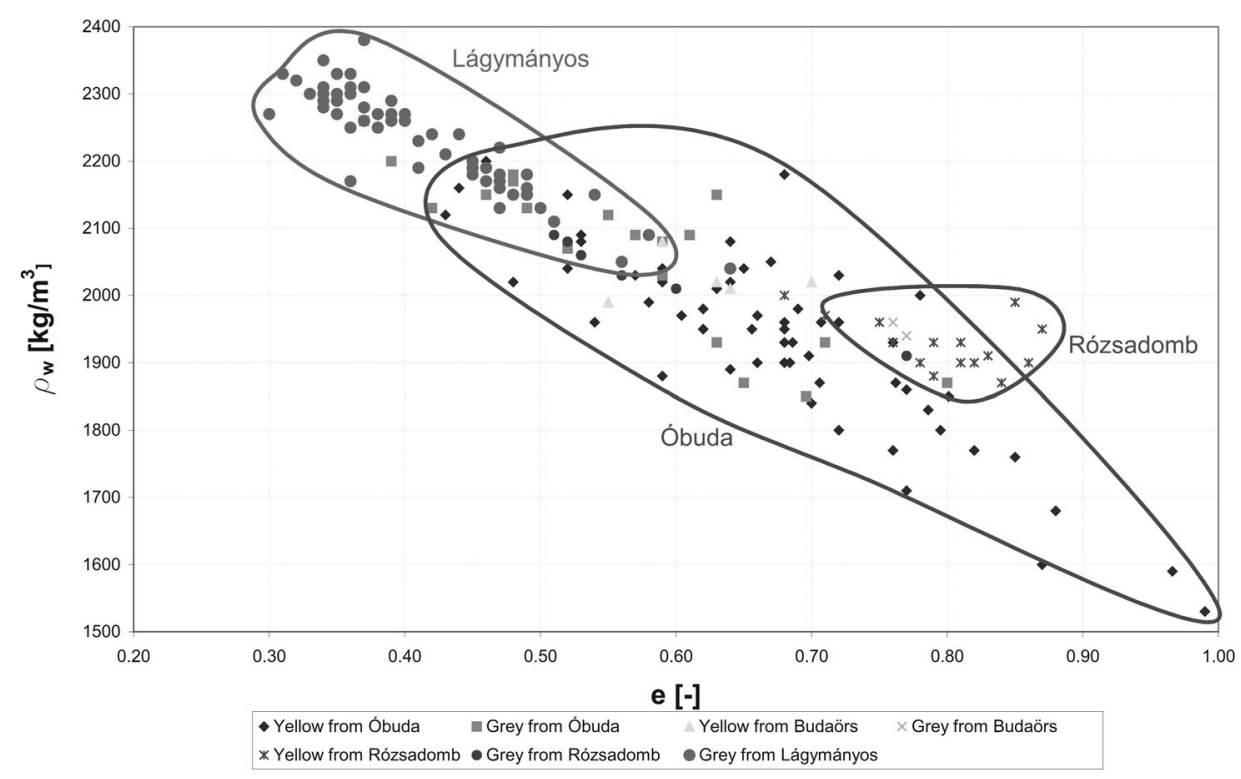

Fig. 16

Areal relationship between void ratio and density

The samples of the KC from Lágymányos are usually from a greater depth than the others; thus the cause of the smaller void ratio could be differences in clay composition, or merely greater depth. Upon comparison it is observable that the samples from Óbuda from the same depth have a lower void ratio, which means that the KC from Lágymányos is more compact.

Finally, plasticity index and cohesion of the $\mathrm{KC}$ from different locations were compared (Fig. 17). The KC from Lágymányos shows considerably higher cohesion than the others. 


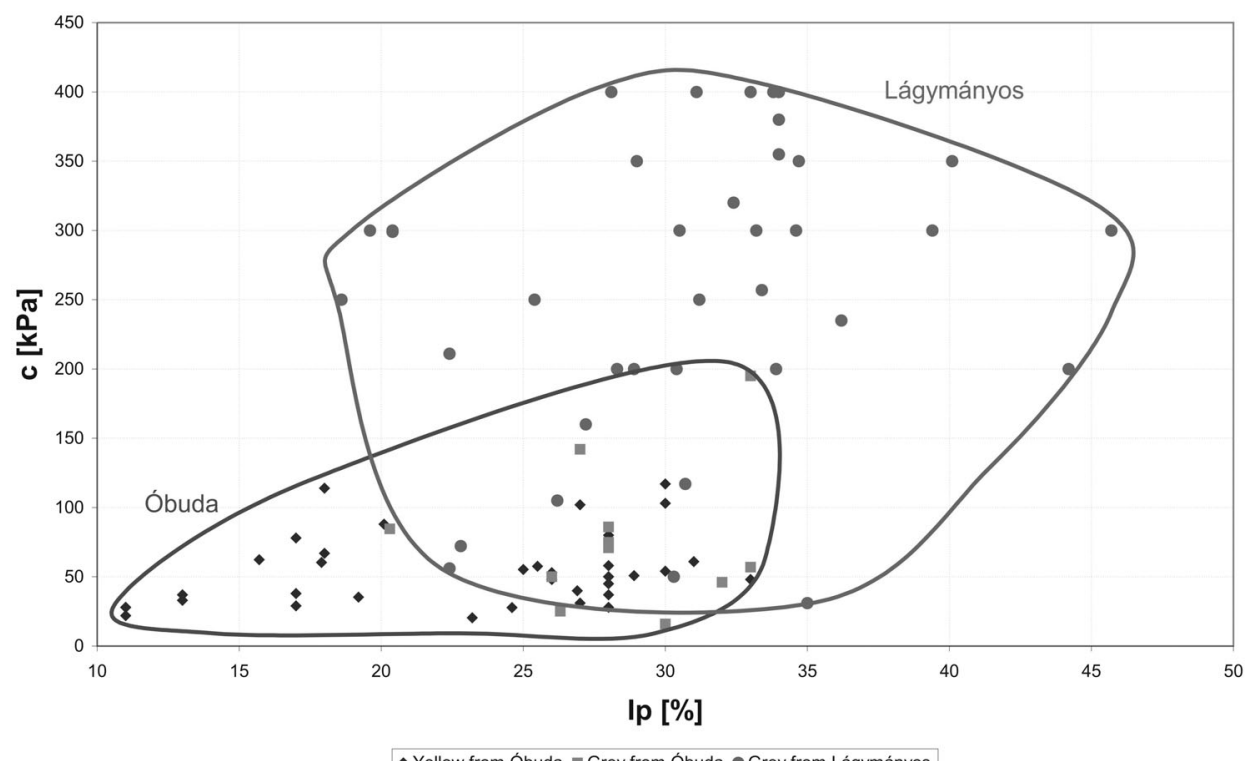

Fig. 17

Areal relationship of plasticity index and cohesion

The reason behind the differences between the KC from Lágymányos and that of Óbuda is that the KC from different locations underwent different stresses through geologic time. According to the geologic descriptions from the area of Lágymányos, more than 500 meters were eroded from the original thickness of the KC. Denudation in Óbuda was considerably less important. This might be the reason that in Óbuda the physical properties of the yellow and gray $\mathrm{KC}$ are sometimes mixed, and that the $\mathrm{KC}$ from Lágymányos is more compact and has greater strength.

\section{References}

Báldi, T. 1983: Magyarországi oligocén és alsómiocén formációk (Hungarian Oligocene and Lower Miocene formations). - Akadémiai kiadó, Budapest, 293 p. (In Hungarian.)

Fodor, T.-né, B. Kleb 1986: Magyarország mérnökgeológiai áttekintése (Engineering geologic survey of Hungary). - MÁFI, Budapest, 199 p. (In Hungarian.)

Hegyi, J., E.Z. Kiss, P. Szlabóczky 1981: Általános földtani eredmények a Budapesti metró vonalak földtani kutatásaiból (General geologic results of the geologic survey of the metro lines of Budapest). - Általános Földtani Szemle, 16., pp. 5-24. (In Hungarian.)

Horváth, T., M. Fáy, Cs. Sándor 2000: A metróvonal mérnökgeológiai adottságai (Engineering geologic conditions of the metro line). - Földtani Kutatás, 37/2, pp. 35-44. (In Hungarian.)

Kalmár et al. 2003: Üledékképződés és kőzettéválás a dél-budai Kiscelli Agyag Formációban, a IV. sz. metró nyomvonalán mélyült fúrásokban (Forming of sediments and rock in the KC Formation by the bore holes of the Metro 4). - MÁFI Évi Jelentése, 2000-2001, pp. 107-119. (In Hungarian.) 
MÁFI 1985: Budapest építésföldtani térképsorozata, alapadatgyújtemény: Gellért-hegy-13, Obuda-4, Rózsadomb-8. Kézirat (Engineering geological map of Budapest, data set: Gellért-hill-13, Óbuda-4, Rózsadomb-8. Manuscript). - (In Hungarian.)

Paál, T. 1975: Regresszió analízis talajfizikai adattömegek esetén (Regression analyses of soil physical database). - Mélyépítéstudományi szemle, 25, pp. 22-30. (In Hungarian.)

Rétháti, L. 1985: Valószínúségelméleti megoldások a geotechnikában (Results of theory of probability in the geotechnics). - Akadémiai Kiadó, 393 p. (In Hungarian.)

Vendl, A. 1932: A Kiscelli agyag (The Kiscell Clay). - A Magyar Kir. Földtani Intézet Évkönyve, 29, pp. 93-155. (In Hungarian.) 